\title{
MIGRASI GAYA HIDUP INTERNASIONAL DAN PEMINGGIRAN MASYARAKAT DI DESA TUJUAN WISATA (Studi di Desa Tugu Selatan Kecamatan Cisarua Kabupaten Bogor Jawa Barat)
}

\author{
International Lifestyle Migration and Social marginalization on the Tourism Village
}

\author{
Lala M. Kolopaking*)
}

Departemen Sains Komunikasi dan Pengembangan Masyarakat, Fakultas Ekologi Manusia IPB

\begin{abstract}
By conducting qualitative research that supported with quantitative data analysis, it has founded that international lifestyle migration which committed by Middle East citizens (Saudi Arabian and Qatar) at South Tugu Village, Cisarua in East Java Indonesia as the destination for village tourism - have been raising social unequality. International lifestyle migration process on this village had occured along with international refugee resettlement from Asian country (Pakistan, Afganistan, Morocco,Myanmar) which is inevitable became as a source of social change. It was begin by the growth of livelihood and economic behavior of local community itself that keenly more dependent on the tourism enterprises. The change of house building and settlement patterns were also followed by the transformation of land occupation and ownership. Moreover, it is identified by manner of speech, eating habits and also public order and security. However, apparently those changes are not enganging with the presence of social welfare equality. On the contrary, such development has been precisely marginalizing the poor community on the village.
\end{abstract}

Keywords: international lifestyle migration, social change, inequality and social marginalization.

\begin{abstract}
ABSTRAK
Dengan melakukan penelitian kualitatif yang didukung dengan analisis data kuantitatif, diketahui bahwa migrasi gaya hidup internasional yang dilakukan oleh warga Timur Tengah (Arab Saudi dan Qatar) di bagian selatan Desa Tugu, Cisarua di Jawa Timur Indonesia sebagai salah satu tujuan untuk pariwisata - telah membesarkan sosial unequality. Proses migrasi gaya hidup internasional di desa ini telah terjadi seiring dengan datangnya turis internasional dari negara Asia (Pakistan, Afganistan, Maroko, Myanmar) yang tidak bisa dihindari menjadi sumber dari perubahan sosial. Itu dimulai dengan pertumbuhan mata pencaharian dan perilaku ekonomi masyarakat setempat itu sendiri yang menjadi lebih tergantung pada perusahaan pariwisata. Perubahan bangunan rumah dan pola pemukiman juga diikuti oleh transformasi pendudukan lahan dan kepemilikan. Selain itu, dapat diidentifikasi dari cara bicara, kebiasaan makan dan ketertiban umum serta keamanan. Namun, rupanya perubahan tersebut tidak mengikutsertakan dengan kehadiran kesetaraan kesejahteraan sosial. Sebaliknya, pembangunan tersebut telah meminggirkan masyarakat miskin di desa.
\end{abstract}

Kata kunci: migrasi internasional gaya hidup, perubahan sosial, ketimpangan dan marginalisasi sosial.

\section{PENDAHULUAN}

Cerminan migrasi internasional dalam konteks perkembangan Provinsi Jawa Barat adalah aliran tenaga kerja keluar dari Jawa Barat pergi ke berbagai negara untuk mencari pekerjaan dengan pendapatan yang lebih baik. Mereka yang pergi dominan perempuan dan berasal dari desa-desa. Pekerjaan yang dimasuki terbanyak adalah sektor domestik di negara-negara di Timur Tengah. Aliran tenaga kerja ini kemudian menjadi sebab dan berkonsekuensi baik terhadap kondisi di negara penerima maupun di desa-desa asal. Ada kajian menemukan, bahwa tenaga kerja migran perempuan internasional ini yang pulang dapat menjadi agen-agen perubahan di desa di daerah pengirim (Tyas, 2010; Poeloengan, 2009). Namun, ada juga yang berpandangan, aliran kepulangan mereka ke desadesa dari bekerja ke luar negeri tidak membawa perubahan mendasar (Zid, 2010; Kolopaking, 2011). Meskipun demikian, yang tidak terbantahkan dari debat tersebut adalah aliran tenaga kerja ini membentuk aliran uang dan jaringan informasi tentang daerah-daerah di Jawa Barat kepada para majikan dari mereka yang bekerja di negara-negara tujuan migrasi. Aliran informasi ini, kemudian menjadi salah satu media promosi tentang keindahan alam Jawa Barat di kalangan para majikan dari negara-negara tempat bekerja khususnya dari Arab Saudi,
Qatar dan Kuwait. Hal ini menjadi faktor penarik mereka untuk datang berkunjung ke daerah-daerah di Jawa Barat, dan Indonesia pada umumnya.

Penelitian ini ingin mengungkapkan, bahwa promosi keindahan alam Jawa Barat oleh tenaga kerja migran internasional tersebut menumbuhkan gejala kebalikan arus migrasi ke Jawa Barat, yang secara konsepsional dikenal sebagai migrasi gayahidup internasional. Migrasi ini berbeda dengan aliran tenaga kerja migran internasional, karena orang melakukan migrasi bukan datang ke daerah maju secara ekonomi. Mereka pergi ke daerah tujuan karena dorongan untuk lari sementara dari kesibukan rutin dan/atau beban sosial, mencari kehidupan lebih santai, mencari iklim yang lebih baik, hingga keinginan untuk hidup lebih dekat dengan alam. Kepergian mereka ke daerah di negara lain juga dapat karena tarikan keunikan daerah tujuan tersebut. Mereka ini bermigrasi dapat hanya untuk melihat dan menjadikan tempat tinggal untuk hidup baru baik sementara bahkan permanen (Croucher, 2009; Benson, 2009; O'Reilly dan Benson, 2009).

Aliran migran gaya hidup internasional yang berkembang di Jawa Barat terjadi karena migran mendatangi daerah dengan "kharakter khas", seperti daerah itu mempunyai situasi alam pedesaan, keindahan alam, makanan dan budaya yang eksotis, 
hingga ingin merasakan gaya hidup alternatif. Sebagaimana diketahui Jawa Barat adalah provinsi di Indonesia yang memiliki banyak tujuan wisata. Tercatat Kabupaten Bogor sebagai salah satu kabupaten di Provinsi Jawa Barat saja memiliki 43 lokasi wisata, baik wisata alam mulai dari air terjun, wisata pegunungan, hingga wisata arena untuk bermain keluarga (Kabupaten Bogor Dalam Angka, 2011).

Migrasi gaya-hidup telah ditelaah oleh banyak peneliti (Benson, 2013;. Casado-Díaz et al, 2004, O’Reilly, 2000, Hayes, 2014). Fokus penelitian cenderung terhadap kepergian orang untuk mengakses sejumlah lokasi tujuan yang mempertimbangkan variasi dari kondisi sosial, budaya, dan biofisik (Benson, 2009). Selain itu, juga fokus untuk menganalisis implikasi interaksi antara migran dengan penduduk lokasi tujuan migrasi. Namun, dalam kaitan tentang dampak terhadap perubahan sosial dan pembangunan daerah tujuan migrasi masih terbatas. Dengan dasar ini, penelitian ini memberi fokus terhadap hal tersebut.

Castles (2003) menunjukkan migrasi dapat berkait dengan trasformasi sosial. Adanya aliran orang, uang dan barang dapat menjadi aliran pengetahuan bagi penduduk baik di negara tujuan maupun penerima. Mengikuti pemikiran Boyle and Halfacree (1998) menarik menelaah migrasi gaya hidup internasional dalam mendorong peningkatan ekonomi masyarakat pedesaan. Sebagaimana disebut sebelumnya migrasi ini cenderung mengalirkan orang dengan pendapatan baik untuk pergi ke berbagai daerah tujuan. Dengan demikian, peluang terjadi peningkatan ekonomi di desa tujuan migrasi cukup besar, dan hal ini akan menjadi sumber perubahan dan perkembangan kehidupan masyarakat.

Mengikuti Fawcett (1989) dan Kritz dan Zlotnik (1992) migrasi dipandang sebagai jaringan penghubung antara dua lokasi kehidupan yang terpisah secara mikro (hubungan sosial antara individu dengan keluarganya) maupun makro (hubungan politik ekonomi antara negara). Hubungan tersebut berawal dari keputusan di tingkat individu sebagai bagian dari anggota keluarga. Lalu, keputusan keluarga pun dipengaruhi pula oleh keadaan sosio-ekonomi setempat yang keadaannya dipengaruhi oleh perkembangan struktur sosial, ekonomi dan politik di tingkat negara dan antarnegara. Proses ini kemudian membentuk jaringan migrasi. Jaringan yang melibatkan sekumpulan ikatan-ikatan interpersonal yang dibina dan terbina untuk kepentingan migrasi berdasarkan ikatan kekerabatan, ikatan kedaerahan dan/atau ikatan perkawanan. Jaringan migrasi yang dibina berfungsi sebagai penghubung sesama migran atau antara migran dengan calon migran, bahkan antara migran dengan penduduk setempat di negara tujuan. Selanjutnya, jaringan ini menentukan sebab dan akibat aliran orang pergi dan pulang serta dampaknya terhadap kehidupan masyarakat baik di daerah penerima maupun daerah pengirim migran (Massey, et al, 1993).

Analisis migrasi memang pada awalnya didasarkan pada dua aliran pemikiran yang saling bertentangan, yaitu pendekatan fungsional dan pendekatan struktural. Integrasi dua pendekatan ini kemudian menjadikan migrasi dipandang sebagai proses aliran orang yang tidak lepas dari perkembangan global. Migrasi dipercaya menjadi penghubung kondisi di tingkat mikro dengan makro yang melibatkan kepentingan perorangan dengan perkembangan masyarakat yang lebih luas. Melalui cara pandang ini, migrasi dianggap sebagai proses hasil kesatuan antara pengambilan keputusan perorangan yang berpengaruh terhadap perkembangan kehidupan di tingkat negara dan antar negara dalam sistem global (Goss dan Lindquist, 1997). Dengan demikian, migrasi termasuk migrasi gaya-hidup internasional dapat mempunyai dampak terhadap pembangunan, dan dampak atas keberlanjutan migrasi itu sendiri. Migrasi dapat menjadi sarana mengurangi ketidaksamaan kemajuan antara negara, sehingga menghentikan migrasi. Namun demikian, migrasi juga dipercaya terus terjadi karena hanya mendorong ketidaksamaan dan mengekalkan keterbelakangan pembangunan. Hal yang terakhir tersebut dinyatakan Castles (1998) sebagai hubungan kontradiksi dari migrasi dan pembangunan.

Penelitian ini dilakukan di pedesaan Jawa Barat dengan aksesibilitas antar wilayah yang cukup baik. Masyarakat desa lokasi penelitian pun telah mengenal sejarah yang panjang terhadap aliran orang pulang dan pergi untuk melakukan migrasi tenaga kerja dan terkena imbas dari perkembangan sebagai daerah wisata.. Namun, merujuk Kolopaking, (2000) yang menyimpulkan, bahwa kemajuan-kemajuan di desa-desa Jawa akibat migrasi tidak langsung mengurangi kesenjangan yang dikenal dalam kehidupan masyarakat. Perlu dicatat juga, proporsi penduduk miskin pedesaan Jawa Barat (10.8\%) lebih tinggi dibanding proporsi penduduk kota (8.3\%). Dengan gini rasio Provinsi Jawa Barat pada tahun 2014 sebesar 0.4 yang masuk kategori sedang dari segi ketimpangan. Pertanyaan penelitian yang kemudian ada, mengapa sebabakibat migrasi, dalam hal ini migrasi gaya hidup internasional tidak mensejahterakan warga desa yang menjadi lokasi tujuan secara merata? Pertanyaan khususnya dalam hal ini, yaitu: (1) bagaimana perilaku migran yang datang ke desa di daerah tujuan migrasi gaya-hidup internasional mendorong perkembangan ekonomi desa ? (2) Mengapa perkembangan ekonomi dapat atau tidak dapat menjadi sumber perubahan kebudayaan masyarakat ?, dan (3) Benarkah migrasi gaya hidup internasional telah mendorong perubahan sosial yang tidak mensejahterakan warga desa secara merata? Jawaban atas pertanyaan-pertanyaan penelitian di atas menjadi tujuan penelitian dan dasar uraian yang disajikan selanjutnya.

\section{METODE PENELITIAN}

\section{Pemilihan Lokasi Penelitian}

Penelitian dilakukan di Desa Tugu Selatan, Kecamatan Cisarua, Kabupaten Bogor, Jawa Barat-Indonesia. Desa ini sengaja dipilih dengan pertimbangan, bahwa Desa Tugu Selatan merupakan bagian dari wilayah wisata Puncak di Kabupaten Bogor yang menjadi tujuan wisatawan baik dari dalam maupun luar negeri, khususnya yang datang dari Timur Tengah. Desa ini dikenal sebagai daerah wisata yang berkembang dan mempunyai ciri kehidupan "Kampung Arab". Sebutan akibat ciri perkembangan wilayah desa semakin dipenuhi atribut untuk melayani "Orang Arab" yang datang dari Arab Saudi dan menetap sementara. Periode kegiatan lapangan dilakukan antara Februari hingga Juni Tahun 2015.

\section{Pengumpulan dan Analisis Data}

Bentuk penelitian ini adalah penelitian kualitatif yang didukung oleh analisis data kuantitatif. Prosedur pengumpulan data didasarkan pada pendekatan penelitian emik yang mengutamakan penjelasan atas fakta sosial dari sudut pandang masyarakat sendiri. Oleh karena itu, kegiatan pengumpulan data dilakukan dengan teknik non-survei selain kajian literatur melalui observasi lapang, wawancara kelompok di satuan pemukiman, wawancara mendalam (in-depth interview) dengan tokoh desa, masyarakat, serta migran dan pengungsi. Data kuantitatif dikumpulkan melalui survei terbatas di dua 
dusun terpilih yang memilih 90 kepala rumahtangga secara acak untuk diwawancara dan mengisi kuesioner terstruktur. Disamping, itu data kuantitatif diambil dari data statistik dan dokumen profil desa.

Data kualitatif dianalisa dengan mengelompokkan informasi berdasarkan jawaban pertanyaan yang didokumentaikan dalam catatan lapangan peneliti. Pengelompokan data ini didasarkan pada upaya menjawab pertanyaan penelitian. Argumentasi-argumentasi yang terkumpul dari wawancara mendalam maupun hasil diskusi kelompok tersebut kemudian dianalisa melalui teknik analisis isi. Hasil analisis data kualitatif selanjutnya menjadi dasar melakukan analisis data kuantitatif dengan sasaran memperkuat bukti-bukti untuk memenuhi tujuan penelitian.

\section{HASIL DAN PEMBAHASAN}

\section{Migrasi Gaya Hidup Internasional dalam Konteks Desa Tugu Selatan}

Kedatangan orang dari negara Arab Saudi ke Desa Tugu Selatan cenderung untuk berwisata menikmati kondisi iklim wilayah yang sejuk dengan keindahan alam yang memikat. Desa Tugu Selatan sendiri letaknya di Kecamatan Cisarua yang sejak lama memang dikenal sebagai daerah tujuan wisata. Seorang tokoh desa menuturkan, awal kedatangan orang dari Arab Saudi (disebutnya sebagai Orang Arab) pada dekade tahun 1980-an. Mereka datang dalam rombongan keluarga dengan tujuan wisata alam. Awal kepergian mereka yang pertama karena ada informasi dan promosi dari para tenaga kerja dari Kabupaten Cianjur yang bekerja di Arab Saudi. Minat berkunjung ke wilayah Cisarua (Desa Tugu Selatan) yang dikenal juga oleh migran gaya hidup internasional dari Arab Saudi sebagai "wilayah puncak" semakin besar akibat dikuatkan oleh ajakan dari kenalan yang telah lebih dulu datang ke Indonesia.

Orang yang datang dari Arab Saudi menyebut wilayah puncak sebagai Jabal Ahdhor (gunung hijau) atau Jabal al Jannah (gunung surga). Daerah yang mereka nilai mempunyai dayatarik untuk dikunjungi akibat keindahan alam. Gambaran yang mereka sebut atas keindahan tersebut adalah tentang bukitbukit yang hijau, udara sejuk, sungai-sungai yang mengalir dan menjadi perumpaan surga bagi orang yang tinggal di Arab Saudi.

Informasi mengenai kondisi Wilayah Puncak menjadi berita yang disampaikan dari mulut ke mulut kepada keluarga dan teman sejawat lainnya ketika pulang ke negara asal. Informasi ini mendorong mereka untuk melihat dan datang. Menurut orang-orang yang datang dari Arab Saudi, "puncak" sebutan kawasan wisata terkenal di Arab Saudi, bahkan beberapa negara di Timur Tengah. Tidak heran, apabila aliran wisatawan ini semakin hari semakin banyak. Hingga saat ini, menurut seorang supir kendaraan sewa, jumlah wisatawan dari Timur Tengah terus meningkat dalam kurun waktu tahun 2012 hingga 2013.

Data Dinas Pariwisata Kabupaten Bogor mencatat jumlah wisatawan asing di sekitar wilayah Cisarua adalah 29.369 orang kemudian meningkat hampir dua kali lipat pada tahun 2014 sekitar 52.174 orang. Asal wisatawan disebutkan petugas kantor tersebut mayoritas adalah mereka yang datang dari negara-negara Timur Tengah. Berdasarkan diskusi kelompok dengan usahawan di Desa Tugu Selatan disebutkan, bahwa wisatawan dari negara-negara Arab Saudi datang ke daerah puncak secara musiman. Umumnya mereka datang berlibur bersama keluarga pada musim-musim liburan anak sekolah di negara asalnya atau sekitar bulan Juni, Juli, Agustus. Musim lain adalah ketika menjelang dan sesudah bulan Ramadan (bulan puasa umat Islam), atau ketika musim haji di Arab Saudi. Pada bulan-bulan yang disebut tadi dikenal oleh masyarakat Desa Tugu Selatan sebagai musim puncak kedatangan orang-orang dari Arab Saudi.

Berdasarkan diskusi kelompok dengan beberapa orang dari Arab Saudi yang sedang berkunjung ke Desa Tugu Selatan, diketahui peningkatan jumlah orang dari Arab Saudi datang ke wilayah puncak akibat kebijakan kerajaan (pemerintah) Arab Saudi memberi cuti 10 hari kerja untuk pegawai setiap tahunnya. Kebijakan ini mendorong banyak orang dari Arab Saudi memilih untuk pergi berlibur ke puncak, sehingga mereka datang tidak hanya pada bulan-bulan liburan seperti disebut di atas, tetapi dapat datang setiap bulan bergantung periode cuti yang didapatnya. Rutinnya kehadiran orang dari Arab Saudi ke wilayah puncak untuk berwisata diklasifikasikan menjadi dua kategori oleh masyarakat desa. Bentuk pertama adalah kedatangan dalam satuan keluarga ketika bulan-bulan puncak kedatangan wisatawan. Kedatangan pada waktu puncak ini sering juga diikuti kedatangan orang untuk berwisata dari negara lain, seperti yang ditemui ketika kegiatan lapangan berasal dari Qatar. Sedangkan, bentuk kedua adalah mereka yang datang secara perseorangan pada bulan-bulan lainnya.

Kehadiran orang dari negara-negara Timur Tengah untuk berwisata menyebabkan masyarakat Desa Tugu Selatan terbiasa berbaur dengan orang dengan perawakan Arab. Kondisi lingkungan seperti ini kemudian dijadikan dasar oleh pemerintah dan pihak UNHCR (United Nation High Commicioner for Refugees) desa ini sebagai tempat penampungan pengungsi dan pencari suaka politik dari Afganistan, Iran, Somalia, Iraq, dan sebagian dari Asia seperti Srilanka dan Myanmar. Mereka tinggal di penampungan dan menetap sementara hingga mereka dapat diterima di negara tujuan yang diinginkan, seperti Australia. Berbekal uang bulanan yang diberikan oleh UNHCR (sekitar satu juta rupiah per bulan) pengungsi ini bertahan hidup berkoloni dalam komunitasnya dan sebagian dari mereka ada juga berbaur dengan kehidupan masyarakat.

Dua aliran orang dengan perawakan dan postur tubuh hampir sama, baik yang datang melalui migrasi gaya hidup internasional dan penampungan pengungsi, masyarakat membedakan dua komunitas yang hidup di "Kampung Arab". Komunitas pertama adalah migran gaya hidup internasional yang menetap sementara di beberapa wilayah pemukiman. Hidup komunitas ini berciri mempunyai bekalan uang yang cukup, cara berpakaian yang lebih bagus dan mampu menyewa rumahtinggal (villa), dan berpergian dengan cara menyewa kendaraan bermotor dan sekaligus membayar jasa guide dan supir. Bahkan, untuk melayani makan seharihari ada yang menggaji juru masak. Sedangkan, komunitas pengungsi berciri kebalikannya, berpakaian sederhana, hidup serba minim, menyewa rumah dari penduduk desa secara berkelompok, dan berpergian lebih sering dengan berjalan kaki atau angkutan umum.

Dari wawancara dengan mereka yang datang dari Arab Saudi disebut uang yang dibawa untuk melakukan perjalanan disiapkan dengan baik. Mereka kebanyakan adalah pegawai pemerintah dan pekerja swasta, dengan membawa uang sekitar US\$ 6.500-8.500 untuk perjalanan 7-10 hari ke Indonesia . Perjalanan umumnya dengan paket melalui agen jaringan wisata yang sudah mapan. Promosi paket perjalanan ini diterima dari mulut ke mulut baik, khususnya berkaitan dengan informasi lokasi tujuan wisata, kemudahan fasilitas menetap, 
nilai tukar uang, serta bagaimana jangkauan transportasi mulai dari Arab Saudi ke Indonesia khususnya wilayah puncak sampai menuju ke Desa Tugu Selatan.

Berdasarkan diskusi kelompok yang dihadiri oleh tokoh pemuda desa, tokoh swadaya masyarakat dan usahawan di Desa Tugu Selatan diprediksi migrasi gaya hidup internasional akan terus berlangsung. Ada empat faktor yang disebut sebagai penentu dalam hal ini. Pertama, wilayah CisaruaBogor sebagaimana disebut merupakan wilayah dengan kondisi iklim sejuk dengan pemandangan nuansa alam yang indah dan tidak dapat ditemui oleh mereka yang hidup di negara-negara Timur Tengah. Kedua, budaya masyarakat Desa Tugu Selatan, di wilayah Cisarua-Bogor pada umumnya telah terbiasa melayani wisatawan. Sikap ini sesuai dengan harapan mereka yang datang sebagai tamu dari negara-negara Timur Tengah dan "disambut oleh tuan rumah dengan baik". Dari catatan diskusi dengan mereka yang datang dari Arab Saudi memang disebut sikap masyarakat desa ramah dan baik untuk memberikan pelayanan dan fasilitas yang diperlukan selama mereka menetap. Ketiga, Desa Tugu Selatan dan wilayah Cisarua pada umumnya dianggap sebagai daerah yang aman dan tidak mendatangkan ketakutan bagi wisatawan asing selama melakukan kunjungan. Keempat, nilai tukar uang di Indonesia lebih rendah dibanding dengan negara asal wisatawan maupun migran. Hal ini menyebabkan pendatang terutama mereka yang datang dari Timur Tengah dapat membelanjakan uangnya secara lebih leluasa dan memperoleh fasilitas/pelayanan yang lebih murah dibanding di negara asalnya.

\section{Sebab-Akibat Kumulatif Migrasi Gaya Hidup Internasional}

Kehadiran orang dari negera-negara lain di wilayah desanya dipandang oleh masyarakat Desa Tugu Selatan mempunyai dampak seimbang antara yang positif dan negatif. Dampak positif yang dirasakan adalah membuka lapangan pekerjaan, meningkatkan kualitas pengetahuan dan pemahaman masyarakat tentang bergaul dengan "orang-luar" di desa, dan ketersediaan dana untuk kegiatan pemeliharaan maupun pembangunan sarana sosial, khususnya tempat ibadah. Sedangkan, dampak negatifnya adalah munculnya peningkatan perilaku menyimpang dalam kaitan hubungan seksual hingga perkembangan prostitusi, dan terganggunya rasa nyaman masyarakat. Berdasarkan kajian lapangan yang dilakukan, faktor sebab-akibat migrasi gaya hidup internasional diuraikan dalam hal tiga hal. Pertama, perilaku migran gaya-hidup internasional mendorong (1) pergeseran pola nafkah dan sumber usaha ekonomi desa; (2) perkembangan pola pemukiman dan perubahan bangunan rumah; (3) penguasaan dan penggunaan lahan; Kedua, migrasi sebagai sumber perubahan kebudayaan, khususnya dalam asepek (4) perubahan berbahasa, pola makan, dan budaya migrasi masyarakat; serta (5) Rasa "nyaman" masyarakat. Faktor ketiga, adalah bahasan secara menyeluruh tentang migrasi gaya hidup internasional yang mendorong perubahan sosial tetapi tidak mensejahterakan warga desa secara merata.

\section{Pergeseran Pola Nafkah dan Sumber Usaha Ekonomi Baru}

Kehadiran orang dari negara lain untuk berwisata di Desa Tugu Selatan memberikan konsekuensi ekonomi berupa perkembangan ekonomi tidak hanya dalam satuan desa, tetapi beberapa desa di Kecamatan Cisarua. Dari kecamatan yang semula didukung oleh kawasan pertanian berkembang
Tabel 1. Besar Pendapatan Masyarakat menurut Jenis Pekerjaan Berbasis Memberi Pelayanan Wisatawan di Desa Tugu Selatan, Tahun 2015

\begin{tabular}{cccc}
\hline No & $\begin{array}{c}\text { Jenis } \\
\text { Pekerjaan }\end{array}$ & Volume & \multicolumn{1}{c}{ Pendapatan } \\
\hline 1 & Jasa Ojeg & $\begin{array}{c}\text { Sekali } \\
\text { jalan }\end{array}$ & $\begin{array}{l}\text { Rp } 30.000- \\
\text { Rp } 100.000\end{array}$ \\
2 & Rental Mobil & $\begin{array}{c}\text { Satu } \\
\text { hari }\end{array}$ & Rp 500.000 \\
& & Satu & Rp 200.000 \\
3 & Sopir Mobil & hari & \\
& & Satu & Rp 50.000-- \\
4 & Penjaga Villa & hari & Rp 250.000 \\
& & Satu & Rp 100.000- \\
5 & Pemandu wisata & hari & Rp 200.000 \\
& & Satu & Rp 150.000- \\
6 & Juru Masak & hari & Rp 200.000 \\
& (hadamah) & Satu & Rp 150.000- \\
7 & Jasa Pijat & orang & Rp 200.000 \\
& & & \\
\hline
\end{tabular}

Sumber: Data Primer (2015)

menjadi lokasi wisata, sehingga menggeser sumber nafkah penduduk dari pertanian ke kegiatan berbasis layanan jasa wisata. Masyarakat Desa Tugu Selatan yang semula bersandar pada kegiatan pertanian (bertani atau bekerja di perkebunan) mulai bergeser ke usaha yang bersandar pada pelayanan jasa wisata.

Dari segi pendapatan diketahui, bahwa kehadiran orang dari negara lain untuk berwisata maupun yang menetap sebagai pengungsi meningkatkan pendapatan. Imbas ini paling dirasakan oleh golongan masyarakat yang memiliki keterkaitan terutama dengan aktivitas wisatawan. Mereka dapat memperoleh pendapatan rata-rata $R p 3.000 .000$ - Rp 5.000.000 per bulan atau lebih tinggi dari nilai Upah Minimum Kabupaten (UMK) Bogor tahun 2015 sebesar Rp 2.590.000. Penghasilan tersebut diperoleh dari ketersediaan lapangan pekerjaan yang muncul dengan kedatangan orang-orang dari Timur Tengah untuk berwisata. Pendapatan ini diperoleh dari sumber nafkah yang beragam mulai dari jasa ojeg atau sewa mobil dan sopir, upah sebagai penjaga villa atau pemandu wisata, upah pelayan restoran makanan Timur Tengah, upah menjadi juru masak, hingga jasa pijat. Variasi pendapatan dari ragam sumber usaha ini dapat dilihat di Tabel 1.

Akses dari masyarakat atas sumber nafkah yang berbasis memberi pelayanan kepada wisatawan tidak mudah. Perilaku ekonomi masyarakat dalam berusaha dan bekerja masih bersandar pada "orang ketiga" sebagai perantara. Misal, warga dari Desa Tugu Selatan yang memberi pelayanan berwisata dari orang-orang berasal dari negara Timur Tengah bergantung pada akses informasi pekerjaan yang diberikan baik oleh orang yang sudah pernah bekerja terlebih dahulu (bisa tetangga atau teman) atau melalui orang lain (desebut masyarakat makelar) yang mempunya akses komunikasi dengan yang akan memberi pekerjaan. Apabila ditawari oleh tetangga atau teman, pekerja dapat memberikan sebagian pendapatannya sebagai bentuk ucapan terimakasih secara sukarela (tidak ditentukan jumlahnya). Sebaliknya apabila memperoleh pekerjaan dari makelar ketentuannya adalah menyetorkan $10 \%$ penghasilannya kepada makelar tersebut. Misalnya seseorang mendapatkan informasi pekerjaan jasa pijat untuk satu orang dengan upah $\mathrm{Rp} 200.000$, maka orang tersebut harus menyetorkan Rp 20.000 kepada makelar kerja dan berlaku kelipatannya. 
Masyarakat yang telah mendapat sumber nafkah berkait dengan kedatangan orang-orang dari Arab Saudi untuk berwisata mengaku senang dan bersyukur. Oleh karena, mereka setelah mendapat akses lalu dipercaya, maka tidak hanya dirinya yang terlibat tetapi sekaligus dapat mengajak anggota keluarga yang lainnya. Misalnya, suami bekerja sebagai penjaga villa atau sopir rental mobil, istri menjadi hadamah (juru masak makanan khas Timur Tengah), dan anak laki-laki menjadi tukang ojek atau pemandu wisata.

"Kehadiran Wisatawan Arab menguntungkan karena meningkatkan kapasitas ekonomi ekonomi dan memberikan lapangan pekerjaan bagi masyarakat.”

(Hasil wawancara pemandu wisata (Laki-laki, 42 tahun) tanggal 23 Februari 2015)

"Wisatawan arab delapan puluh persen memiliki dampak yang positif dari segi ekonomi, satu Wisatawan Arab biasanya melakukan transaksi untuk menyewa villa, menyewa tukang masak seratus lima puluh sampai dua ratus ribu per hari, kemudian menyewa mobil atau ojek."

(Hasil wawancara hadamah (Perempuan, 49 tahun) tanggal 21 Februari 2015)

Pada saat musim puncak kedatangan orang dari negera-negara Timur Tengah disebut pengurus sebuah lembaga keuangan dan penukaran uang di Kecamatan Cisarua, perputaran uang di wilayah itu berkisar antara 15-16 milyar per hari. Namun, manfaat ekonomi yang terlihat besar ini cenderung dinikmati oleh mereka yang memiliki aset serta mampu menjalin komunikasi dengan orang datang sebagai wisatawan. Di sisi lain, bagi masyarakat yang tidak memiliki aset dan kemampuan untuk bergaul, mereka tidak terlalu mendapat keuntungan. Mereka cenderung menjadi penonton dan merasakan dampak negatif dari perilaku mereka yang datang bersenang-senang keluar dari kebosanan hidup di negaranya. Tingginya jumlah wisatawan dari negara asal Timur Tengah, khususnya Arab Saudi yang masuk dan tinggal sementara di desa memang membiasakan warga desa berhadapan dengan orang dari negara lain. Meskipun demikian diakui oleh masyarakat, ada sebagian dari mereka yang datang untuk berwisata membuat tidak nyaman karena bertindak berlebihan dan bertentangan dengan etika budaya masyarakat.

Mengikuti hasil wawancara kelompok di tingkat desa, disebutkan bahwa perkembangan migrasi gaya hidup internasional memang membangunkan ekonomi desa. Namun, prosesnya diikuti oleh semakin dirasakan ketidaksamaan yang ada antar lapisan masyarakat. Hal ini akibat aliran orang dari Arab Saudi atau negara Timur Tengah lain ke Desa Tugu Selatan dikembangkan dalam bentuk jaringan migrasi dengan dasar penanam modal dari luar desa. Para pemodal ini kemudian menguasai informasi tentang fasilitas-fasilitas wisata yang dapat dijadikan usaha pelayanan, mulai dari biaya untuk tinggal hingga fasilitas transportasi. Usaha-usaha ini cenderung melibatkan penduduk desa sebagai pekerja. Perlahan-lahan di kalangan masyarakat desa yang sudah merasa menjadi pekerja mulai ada yang menjual aset-aset yang dimiliki kepada pemodal dari luar desa, karena tergiur mendapatkan uang secara cepat. Hal ini membuat kebanyakan masyarakat desa justru menjadi pekerja di usaha yang berkembang akibat aliran migrasi gaya-hidup internasional. Pada akhirnya migrasi gaya hidup internasional cenderung dikendalikan oleh jaringan migrasi yang lebih memberi manfaat kepada pemodal yang berasal dari luar desa.

Kebanyakan warga desa selanjutnya hidup bergantung pada usaha ekonomi dengan basis menjual jasa untuk kepentingan orang luar di wilayah tinggalnya sendiri. Bahkan, kajian menemukan ada kalangan masyarakat yang semakin bergantung dari aliran migrasi gaya hidup internasional ini kemabli masuk didorong atau ditarik untuk bekerja di Arab Saudi dan Qatar sebagai tenaga kerja luar negeri.

\section{Perkembangan Pola Pemukiman dan Perubahan Bangunan Rumah}

Desa Tugu Selatan merupakan salah satu desa yang memberi tempat untuk tinggal bagi mereka dari negara-negara Timur Tengah untuk berwisata. Desa ini juga telah dipilih menjadi lokasi pengungsian internasional. Perkembangan yang dirasakan kemudian adalah wajah permukiman mengalami perubahan dari desa pertanian menjadi desa wisata yang menampung kunjungan orang dari negara-negera Timur Tengah.

Kini telah tumbuh wilayah yang menjadi pusat tempat tinggal wisatawan. Kondisi pemukimannya terlihat lebih rapi dan tertata dengan bangunan yang lebih menyerupai rumah-rumah

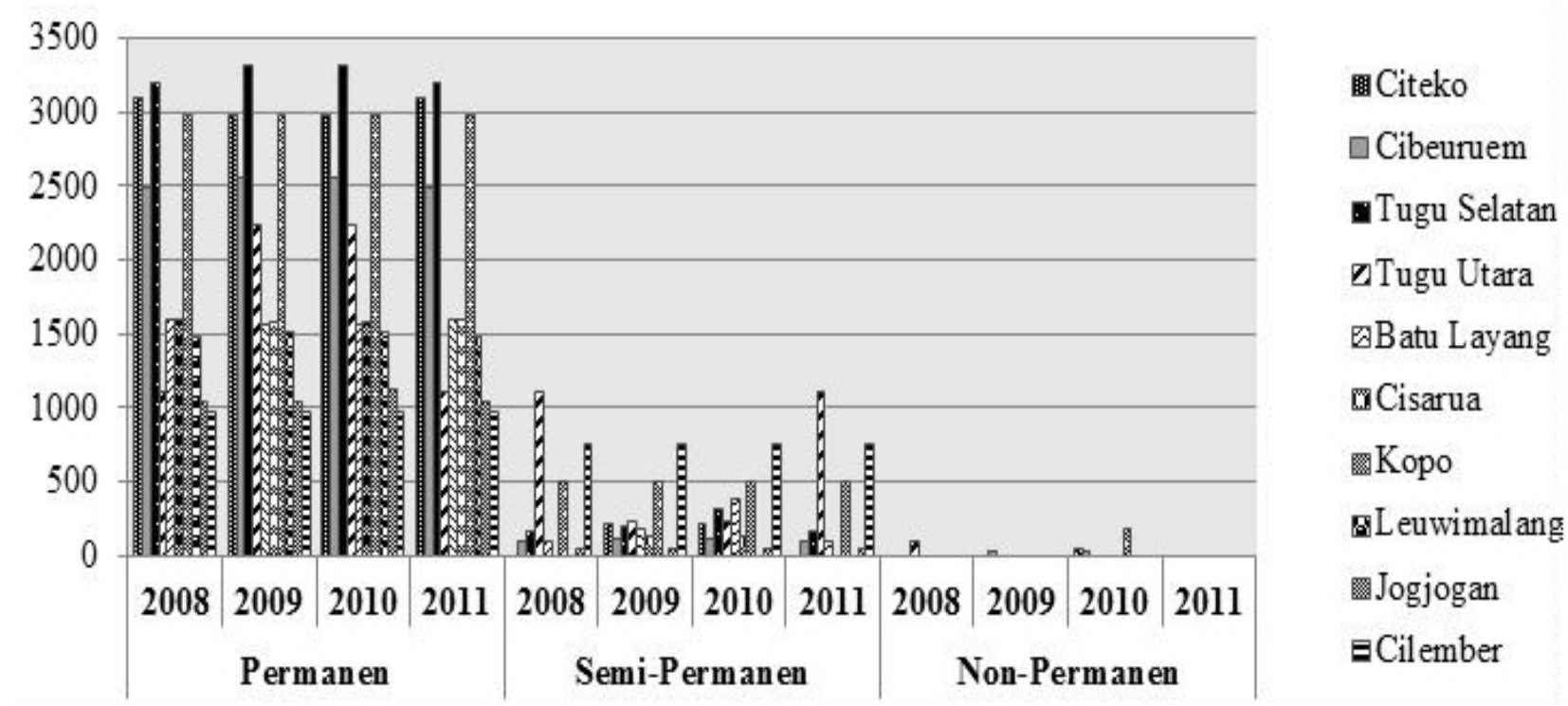

Sumber: Cisarua Dalam Angka Tahun 2008-2011

Gambar 1. Jumlah Bangunan Permanen, Semi-Permanen, dan Non-Permanen di Cisarua 


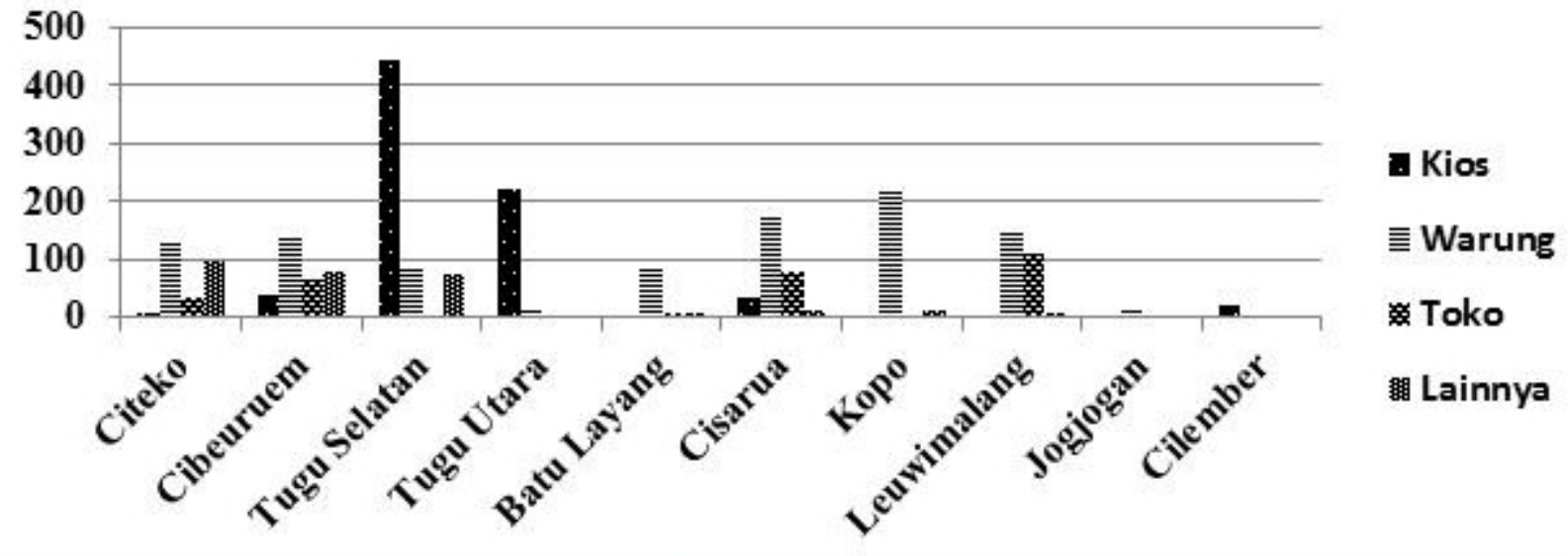

Sumber: Cisarua Dalam Angka (2013)

Gambar 2. Jumlah kios, toko, dan warung di Kecamatan Cisarua

di kota besar. Umumnya orang-orang yang datang dari Arab Saudi atau negara Timur Tengah lainnya menginginkan rumah dengan fasilitas yang memadai meliputi kamar tidur, ruang keluarga, dapur, dan halaman terbuka yang tertata dengan rapi. Saat kegiatan lapangan, pemukiman seperti ini mempunyai prasaranan jalan yang baik. Dapat dikatakan bahwa kondisi lingkungan pemukiman mereka yang berwisata lebih tertata dibandingkan pemukiman penduduk asli desa pada umumnya.

Karakteristik dari pemukiman dalam satuan desa dengan berkembangnya migrasi gaya hidup internasional menunjukkan bahwa area-area yang ditempati oleh mereka yang datang untuk berwisata lebih berkembang dibanding area bagi masyarakat lokal. Tempat tinggal mereka ini berada dekat dengan pusat pemerintahan desa, jalan raya, pusat-pusat ekonomi (pasar, kios, toko), juga memiliki akses transportasi yang mudah. Sebaliknya, masyarakat lokal justru tinggal tersisih di pinggiran desa yang jika dibandingkan relatif jauh dari pusat-pusat fasilitas yang dapat dinikmati wisatawan. Meskipun, dari 145 kepala keluarga yang dijadikan sumber informasi sekitar 127 rumahtangga $(87,6 \%)$ diketahui telah tinggal dalam bangunan rumah tembok (permanen).

Pembangun fasilitas wisata terjadi secara masif di Desa Tugu Selatan, baik berupa villa, hotel, restoran, swalayan, dan berbagai fasilitas lainnya. Perkembangan jumlah fasilitas tersebut terus bertambah seiring dengan semakin banyaknya pendatang yang menikmati suasana Puncak. Berdasarkan data Kecamatan Cisarua Dalam Angka (2008-2011) diketahui kondisi bangunan di desa-desa kawasan tersebut didominasi oleh bangunan permanen baik yang diperuntukkan sebagai hunian, vila, maupun restoran (Gambar 1) .

Pembangunan villa dan hunian lainnya diketahui cenderung dilakukan oleh warga luar Desa Tugu Selatan. Proses ini membuat pertumbuhan pusat-pusat ekonomi seperti kios, toko, dan warung-warung kecil juga banyak bermunculan. Hadirnya orang dari Arab Saudi atau dari negara-negara Timur Tengah menyebabkan terbukanya peluang usaha untuk berbagai keperluan khas Timur Tengah. Kios dan toko menyediakan kebutuhan wisatawan mulai dari jasa pelayanan perjalanan (travel agent), kayu gaharu yang merupakan kebutuhan pesta dan wewangian orang Timur Tengah, bahan makanan khas Timur Tengah, maupun kebutuhan pakaian. Keberadaan kios maupun toko tersebut banyak terdapat di Desa Tugu Selatan (Gambar 2).

Berbeda dengan upaya pihak luar-desa mengembangkan usaha memanfaatkan kedatangan orang dari negara-negera Timur Tengah berwisata dari pihak-luar desa, warga desa juga membuka warung-warung kecil di dalam pemukimannya. Konsumen dari warung-warung ini adalah warga desa dan pengungsi untuk membeli kebutuhan sehari-hari. Kehadiran warung-warung ini menjadi pengungsi yang menyewa rumah warga dan warga desa sendiri sebagai konsumen. Warungwaring ini menyatu dengan pemukiman warga dan dekat dengan rumah-rumah tinggal warga desa yang disewa oleh para pengungsi.

\section{Penguasaan dan Penggunaan Lahan}

Potensi perkembangan pariwisata di puncak, khususnya Kecamatan Cisarua semakin memberikan peluang bagi pemilik modal untuk mengembangkan bisnis di wilayah tersebut. Saat ini penguasaan lahan semakin didominasi oleh orang luar Desa Tugu Selatan, mereka mayoritas berasal dari Jakarta. Hasil survei terbatas yang mewawancarai 90 warga desa memang ditunjukkan, bahwa tidak ada kepala keluarga rumahtangga pertanian. Jumlah mereka yang bekerja di bidang pertanian dan mengaku sebagai buruhtani juga kecil (13,3\%).

Berdasarkan diskusi dengan warga desa yang bekerja sebagai buruhtani disebutkan warga desa cenderung bekerja sebagai pengelola lahan-lahan milik orang luar. Lahan kebanyakan sudah dimanfaatkan atau disiapkan sebagai lokasi villa maupun bangunan tempat usaha lainnya. Mereka yang menguasai lahan tidak hanya oleh Warga Negara Indonesia. Ada penguasaan oleh orang luar, seperti mereka yang berasal dari Arab Saudi. Penguasa lahan ini awalnya adalah orang yang pernah datang melakukan perjalanan wisata. Mereka kemudian melihat peluang yang ada, dan dengan berhubungan dengan masyarakat lokal yang menjadi makelar, mereka menyewa tanah beserta bangunan villa dalam jangka waktu 5-10 tahun. Tanah dan bangunan yang disewa tersebut kemudian disewakan untuk tinggal sementara kepada orang lainnya yang datang dari Arab Saudi lengkap dengan pelayan dan penjaga yang dipekerjakan sebagai pengelola.

Hasil survei terbatas juga memperlihatkan pekerjaan atau usaha non-pertanian yang digeluti warga desa berkait dengan pengembangan wisata. Ada yang menjadi tukang atau buruh bangunan (13,3\%), sebagai penjaga villa dengan sekaligus menjadi supir untuk keperluan villa tersebut $(10,0 \%)$, guide wisata (1\%), pedagang makanan dan pengelola bengkel kendaraan (13,3\%). Sisanya, adalah mereka yang bekerja sebagai karyawan swasta dan guru/ustad. Dari data ini menunjukkan warga Desa Tugu Selatan adalah warga yang minim lahan, mereka hanya mempunyai lahan dalam satuan 


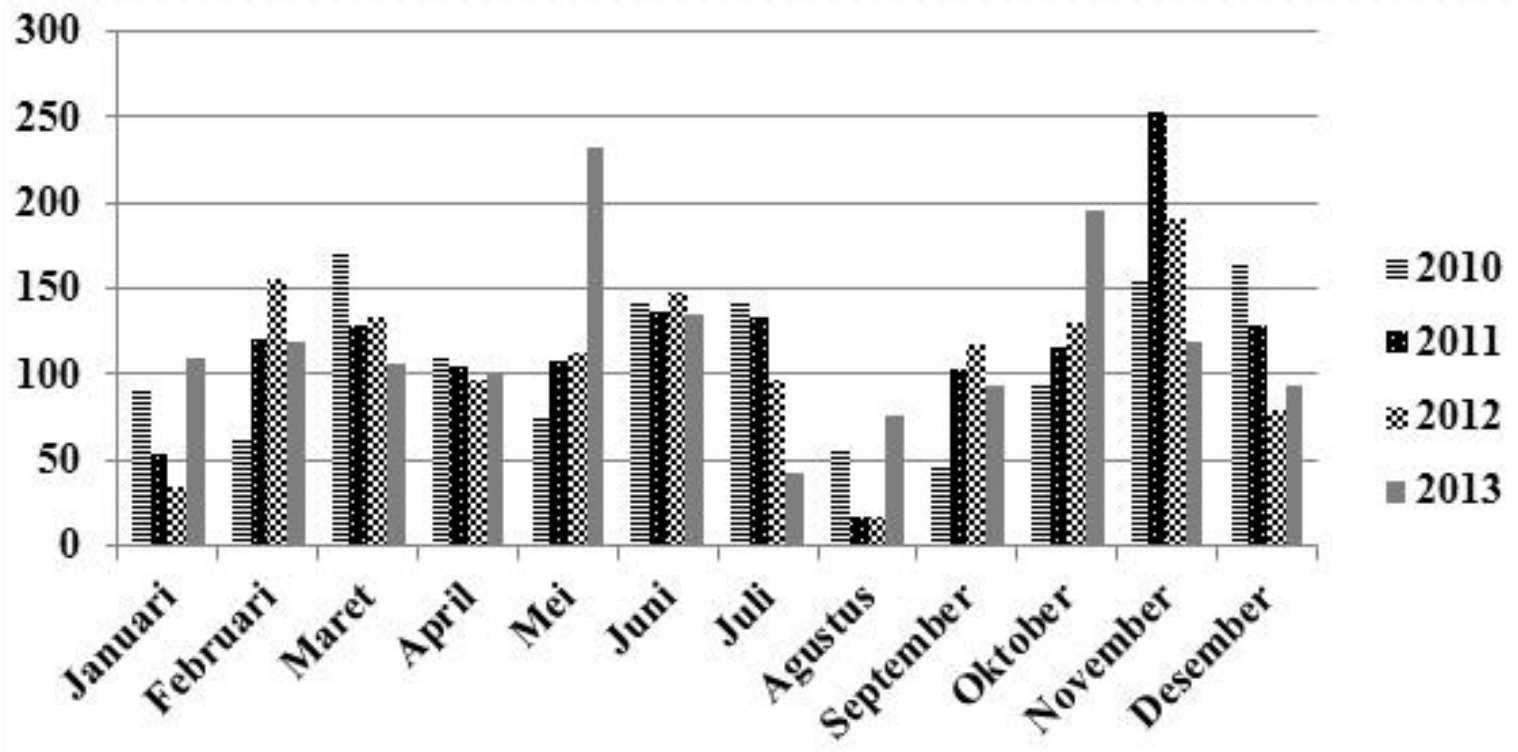

Sumber: Cisarua Dalam Angka (2010-2013)

Gambar 3. Jumlah Pernikahan di Kecamatan Cisarua per Bulan Tahun 2010-2013

bangunan rumah saja. Mereka bertahan hidup dengan menjual jasa dan keterampilan yang dimilik. Sebagai misal, kasus rumahtangga guru membagi ruang bangunan rumahnya untuk warung yang menjual untuk kebutuhan sehari-hari. Demikian juga mereka yang menjadi buruh bangunan, istrinya membuka warung berjualan makanan.

Selain untuk villa dan tempat tinggal, penguasaan lahan yang dikuasai oleh orang luar sebagai kios, toko, dan restoran yang menyediakan kebutuhan-kebutuhan pendatang di desa mempunyai mekanisme pengelolaan yang sama. Sebagaimana yang berlaku untuk sektor usaha villa dan hunian, pusatpusat perekonomian yang dikuasai oleh orang luar juga mempekerjakan warga desa yang tidak memiliki kuasa terhadap lahan di wilayah mereka sendiri. Kajian lapangan juga menemukan, bahwa tergesernya sektor pertanian ke pariwisata disebut tokoh-tokoh Desa Tugu Selatan mengakibatkan konversi lahan yang sangat masif. Sektor pertanian diakui masih hidup, tetapi melibatkan sebagian kecil golongan masyarakat yang mampu menyewa lahan dari pemilikinya (orang luar) dan lahannya belum dibangun sebagai villa atau pun tempat usaha lainnya. Masyarakat yang mampu menyewa lahan tersebut kemudian cenderung mempekerjakan kembali warga desa sebagai buruh tani untuk menggarap lahan sewaan sebagai lokasi pertanian dengan luasan kisaran dibawah 500 $\mathrm{m}^{2}$.

\section{Perubahan Berbahasa dan Pola Makan: Pertukaran Unsur Kebudayaan}

Sebagaimana disebut sebelumnya, bahwa interaksi langsung dengan orang yang datang berwisata dari Arab Saudi tidaklah mudah. Survei terbatas menemukan sekitar 30,3 \% saja warga yang dapat berinteraksi dengan baik dan mendapat keuntungan dari proses tersebut. Meskipun demikian, aliran orang dari negara-negara Timur Tengah---Arab Saudi pada khususnya memberikan dampak yang signifikan bagi perkembangan kebudayaan. Pertukaran unsur kebudayaan bermula dari upaya warga desa belajar berbahasa Arab agar dapat berinteraksi langsung. Perilaku ini menularkan efek terbiasa bergaul dengan pendatang dari kebudayaan yang berbeda.

Keluar masuknya orang dari "luar negeri" tidak lagi menjadi hal asing bagi penduduk Desa Tugu Selatan. Bahasa dijadikan masyarakat untuk mendekatkan diri dari segi budaya. Hal ini bermula dari transaksi ekonomi. Rata-rata kios maupun toko yang melayani kebutuhan orang dari Arab Saudi menggunakan Bahasa Arab, termasuk nama toko juga bertuliskan Huruf Arab. Hal ini meluas, tidak sedikit di sepanjang jalan area Kecamatan Cisarua berderet restoran-restoran yang menawarkan sajian makanan khas Timur Tengah yang umumnya buka pada malam hari. Namun, proses ini pun tidak mampu melibatkan dan menguntungkan kepada berbagai kelompok warga desa secara merata. Lebih lagi, warga desa sulit berinteraksi dengan pengungsi yang cenderung berbahasa Inggris. Dari pengamatan, warga desa yang tinggal di sekitar villa tempat tinggal sementara orang yang berwisata dari Arab Saudi cenderung cepat melafalkan Bahasa Arab untuk komunikasi sehari-hari. Tidak jarang, orang dari Arab Saudi ada yang mencoba berbahasa Indonesia. Namun, Bahasa Inggris tidak berkembang di Desa Tugu Selatan karena pengungsi yang biasa bercakap dengan Bahasa Inggris cenderung tertutup dan mengisolasi diri terhadap warga desa.

Pertukaran kebudayaan selain melalui bahasa adalah dengan pola makan. Pengertian pola makan termasuk dari waktu, cara dan jenis makanan yang dikonsumsi. Pola makan warga desa yang dekat dengan orang dari Arab Saudi terkena pengaruh untuk mengkonsumsi makanan dari Timur Tengah. Pengaruh ini meluas ke kalangan warga karena mereka mampu memasak makanan Timur Tengah dan dipercaya menjadi hadamah (juru masak) bagi keluarga yang datang dari negaranegara Timur Tengah, sering membawa sebagian makanan ke rumahnya dan dimakan bersama keluarga. Secara tidak langsung kondisi tersebut mempengaruhi selera pola makan budaya asli (sunda) dengan selera Timur Tengah. Belum lagi, banyak restoran-restoran besar dan menengah ikut menjajakan menu makanan Timur Tengah. Dari pengamatan lapangan, pertukaran pola makan ini tidak berjalan searah, banyak orang dari Arab Saudi atau mereka yang datang dari negara Timur Tengah lain mencicipi menu makanan Sunda. Dari wawancara dengan mereka yang datang dari Arab Saudi, mereka sudah berkenalan dengan makanan Indonesia di negaranya.

\section{Rasa "Nyaman” Masyarakat}


Dari pengalaman tinggal di Desa Tugu Selatan yang terbuka bagi orang asing ditemukan dua pandangan yang berkembang dalam kehidupan warga desa. Pandangan pertama, adalah pandangan dari mereka yang percaya kedatangan orang dari negara lain dan membawa uang akan memungkinkan percepatan perubahan ekonomi. Namun demikian, pandangan kedua adalah perubahan tersebut dipandang akan memunculkan resiko dalam hal ketertiban dan keamanan. Bagi warga desa yang dapat berinteraksi langsung dengan wisatawan atau migran pengungsi dan mendapatkan keuntungan, kehadiran mereka dianggap sebuah ancaman. Namun bagi sebagian lain yang tidak berinteraksi langsung dan tidak mendapat keuntungan, kehadiran orang asing ini menjadi ancaman bagi kelanjutan hidup di desanya. Pengertian ancaman ini sebenarnya kekhawatiran dari masyarakat pernah. Oleh karena perilaku orang-orang asing di desa ini pernah menjadi pemicu percepatan perkembangan pelacuran dan terjadi tindakkekerasan akibat pro dan kontra atas kehadiran mereka dari warga desa.

Perkembangan pelacuran pernah menjadi hal yang meresahkan masyarakat. Sebab pelaksanaannya disebut seorang tokoh agama dibungkus dengan satu metode pernikahan kontrak dengan difasilitasi oleh oknum pemerintah desa. Meskipun perempuan yang dinikah kontrak bukan penduduk asli Desa Tugu Selatan, namun masyarakat tetap resah karena pada saatnya dapat melibatkan penduduk asli perempuan.

\section{“..baik mereka yang berwisata maupun menjadi pengungi memang tidak berinteraksi langsung dengan kami, namun saya khawatir karena punya anak perempuan, takut mengikuti budaya mereka sebab sebagian dari orang-orang itu suka bawa perempuan..."}

(Hasil wawancara warga (Perempuan, 47 tahun) tanggal 24 Februari 2015)

Tidak ada data khusus yang menjelaskan tentang peristiwa kawin kontrak, namun data jumlah pernikahan di Cisarua menunjukkan jumlah pernikahan yang relatif lebih tinggi pada bulan-bulan musim kedatangan orang dari negara-negara Timur Tengah, khususnya Arab Saudi berwisata, yaitu dari Mei hingga November. Lihat Gambar 3. Hal tersebut diduga bahwa sebagian pernikahan terutama praktek kawin kontrak banyak terjadi pada bulan tersebut.

Menurut warga yang menganggap kehadiran orang asing sebagai ancaman menyebutkan juga, bahwa faktor yang dapat menyulut perselisihan, yaitu perbedaan budaya terkait aktivitas pada waktu malam. Warga desa menggunakan waktu malam sebagai waktu istirahat, sebaliknya mereka yang datang dari Arab Saudi cenderung memulai aktivitasnya sejak pukul delapan malam. Mereka bercengkrama, melaksanakan pesta, menyalakan musik serta petasan pada malam hari. Dari seorang tokoh agama yang ditemui, bahwa hal tersebut mengganggu kenyamanan waktu istirahat warga. Berbeda dengan mereka dari Arab Saudi sebagai wisatawan, ancaman dari pengungsi adalah gaya hidup yang jorok dibanding warga desa. Perilaku membuang sampah sembarangan serta tidak peduli pada kebersihan lingkungan membuat masyarakat terganggu. Selain itu kekhawatiran atas hadirnya sekte ajaran tertentu yang mungkin dibawa oleh pengungsi menyebabkan masyarakat protektif dan cenderung menghindari kontak dengan pengungsi.

\section{Marginalisasi Masyarakat Desa dan Migrasi}

Hasil kajian yang diuraikan di atas menunjukkan, bahwa dampak migrasi gaya hidup internasional terhadap desa tujuan sangat berkait dengan pengembangan dan perkembangan dari desa itu sendiri. Gejala umum yang menjadi benang merah dari dampak berbagai faktor akibat aliran orang datang dan pulang di Tugu Selatan sebagai desa lokasi penelitian adalah mengenal ketidaksamaan dampak migrasi dari masyarakat. Apabila merujuk Lipton (1980) yang telah lama menemukan dan mengingatkan ada ketidaksamaan dampak migrasi terhadap pembangunan desa, maka migrasi gaya hidup internasional tidak dapat disimpulkan sebagai faktor penentu utama perkembangan desa tujuan migrasi. Oleh karena ketidaksamaan dalam kehidupan desa tujuan migrasi gaya hidup internasional dapat telah wujud jauh sebelum terjadi aliran orang dan datang ke desa tersebut.

Ketidaksamaan dalam masyarakat dan kemajuan terus menjadi fokus penelitian karena kondisi ini dapat menjadi sebab maupun akibat migrasi (Black, Natali, Skinner, 2005). Sebab dan akibat migrasi internasional sendiri memuat ketidaksaman mulai dari aras rumah tangga, komunitas, regional baik di negara pengirim maupun penerima. Bahkan, kehadiran arus aliran tenaga kerja buruh internasional sendiri menunjukkan adanya ketimpangan kemajuan antar negara.

Ketidaksamaan dampak migrasi gaya hidup internasional yang terjadi di Tugu Selatan disebabkan perbedaan akses masyarakat terhadap peluang-peluang kemajuan yang hadir dari migrasi. Berbagai perubahan dalam aspek ekonomi, pola pemukiman, penguasaan dan penggunaan lahan, hingga pergerak kebudayaan cenderung akibat perubahan yang terjadi eksklusif dan menyingkirkan sebagian orang yang mempunyai keterbatasan modal, keterampilan akibat terlilit kemiskinan Proses migrasi juga berkembang dalam bentuk jaringan pengelolaan aliran orang yang hanya menguntungkan sebagian kecil orang dan menyisakan sedikit manfaat untuk warga desa tujuan wisata.

Penelitian ini menguatkan proposisi utama dari teori jaringan dan teori kelembagaan migrasi internasional. Aliran aliran orang antar negara yang dalam hal ini migrasi gaya-hidup internasional berkembang melalui basis jaringan migrasi yang melibatkan berbagai pihak mendapat keuntungan. Aliran warga negara dari Arab Saudi dan Qatar berlibur ke Tugu Selatan sebagai desa tujuan wisata semakin banyak karena mengandalkan hubungan pertalian saudara dan rekan usaha layanan wisata hingga membentuk lembaga usaha berbasis wisata. Mengutip satu proposisi teori kelembagaan migrasi internasional, maka aliran orang yang dikelola menjadi sebuah kelembagaan yang mapan, maka aliran tersebut sulit dihentikan. Oleh karena semua pihak akan terus berusaha menjaga dan menarik sebanyak-banyaknya keuntungan dari aliran orang tersebut. Namun, soal dari pengalaman migrasi gaya hidup internasional ke DesaTugu Jaya, keuntungan yang dihasilkan dari lembaga usaha mengenal ketidaksamaan, dan bahkan menyikirkan orang-orang yang tidak mempunyai posisi tawar usaha.

Apabila Kolopaking (2000) menunjukkan, bahwa aliran tenaga kerja internasional di Jawa sulit dihentikan sebagaimana proposisi teori kelembagaan. Oleh karena semua yang terlibat orang menarik keuntungan dari aliran orang tersebut dengan melakukan eksploitasi tenaga kerja yang menjadi buruh migran. Dalam konteks aliran orang datang dan pulang dalam migrasi gaya-hidup internasional ke Tugu Selatan sebagai desa tujuan wisata di Jawa Barat, kelangsungan aliran orang tersebut juga cenderung sulit dihentikan. Dengan ciri tidak hanya menumbuhkan ketidaksamaan, tetapi meminggirkan dan melanjutkan ekspolitasi terhadap warga desa tujuan migrasi untuk menikmati keuntungan. Hal ini terjadi karena 
perkembangan dan perubahan yang terjadi di desa tujuan migrasi gaya-hidup internasional cenderung hanya berorientasi memberi pelayanan kepada migran. Dengan pengelolaan prosesnya tidak diikuti oleh perencanaan yang baik dari pemerintah yang memberi perhatian terhadap kepentingan warga desa tujuan migrasi. Akibatnya, mereka kemudian kalah bersaing dalam menarik manfaat dari aliran orang akibat migrasi gaya-hidup internasional.

Perhatian pemerintah yang kurang terhadap pengembangan masyarakat secara mendasar dari desa tujuan migrasi juga menjadi sebab ketidaksamaan yang ditimbulkan oleh migrasi. Sebagaimana diketahui, Cisarua memang telah lama dikenal sebagai daerah tujuan wisata. Perhatian hanya dilihat dari pandangan pihak luar, seperti menjaga keindahan atau keamanan bagi mereka yang datang. Sebagai misal, desadesa tujuan migran gaya hidup internasional di Cisarua dipilih menjadi lokasi penampungan pengungsi internasional karena pandangan perhitungan "orang luar". Masyarakat yang telah memberi tempat pada pengembangan pemukiman Komunitas Arab diduga akan menerima pengungsi karena postur fisik dan agama pengungsi mirip orang dari Arab Saudi. Semua pertimbangan perkembangan cenderung mengikuti pemikiran "orang luar" dan kurang mengungkap pandangan dan kepentingan masyarakat desa tujuan migrasi sendiri.

Hasil penelitian ini memperkuat proposisi bahwa migrasi tidak dapat mengurangi ketidaksamaan. Sebagaimana teori jejaring migrasi internasional memang ditemukan, bahwa aliran orang dari migrasi gaya hidup internasional berkembang dan bersandaran pada jejaring migrasi yang jauh dari jangkauan pengaturan pemerintah. Kelembagaan migrasi gaya hidup internasional itu pun menguatkan kelembagaan pembangunan yang meminggirkan masyarakat desa. Akibatnya, migrasi gaya hidup internasional meminggirkan segolongan orang dan semakin menumbuhkan ketidaksamaan dalam masyarakat.

\section{KESIMPULAN DAN SARAN}

\section{Kesimpulan}

Migrasi gaya hidup internasional dalm konteks perkembangan dan pengembangan Desa Tugu Selatan ditemukan menjadi satu faktor sumber perubahan sosial yang yang tidak mensejahterakan warga desa secara merata dan tetap menguatkan proses peminggiran masyarakat desa tujuan migrasi. Hal ini akibat migrasi gaya hidup internasional lebih menguntungkan "orang luar" sebagai pemilik modal yang mampu berinvestasi untuk menyelenggarakan dan mendukung kegiatan aliran orang datang dan pulang. Hal ini terus berlangsung karena peran negara lemah dan gagal melindungi serta mencegah warga desa untuk menjual asetaset yang dimiliki karena tergiur mendapat keuntungan cepat dalam jangka waktu pendek.

Dampak aliran orang yang terjadi di desa tujuan migrasi di Jawa Barat akibat dari perkembangan migrasi gaya hidup internasional perlu menjadi fokus perhatian pembuat kebijakan, khususnya Pemerintah Desa. Setiap perubahan akibat hadirnya "orang luar" dalam kehidupan desa semestinya dapat memberikan dampak yang bermanfaat bagi masyarakat dan desa juga agar maju dan tetap mampu berdaulat. Lahirnya Undang-undang Nomor 6 Tahun 2014 tentang Desa menjadi peluang bagi pemerintah desa dan pemerintah daerah untuk kembali menyusun pembangunan desa yang menjadikan migrasi gaya hidup internasional lebih mendatangkan manfaat bagi masyarakat dan menghentikan peminggiran masyarakat.

\section{Saran}

Langkah yang perlu diperhatikan dalam hal ini adalah menguatkan kelembagaan usaha masyarakat desa dalam kaitan pengelolaan pelayanan wisata. Hal ini perlu dituangkan dalam rancangan pembangunan desa jangka memengah dan tahunan yang dilaksanakan dengan menggunakan dana pembangunan dari pemerintah maupun dari pemerintah desa sebagaimana diamanatkan oleh undang-undang.

\section{DAFTAR PUSTAKA}

Benson, 2013. Postcoloniality and privilege in new lifestyle flows: the case ofnorth Americans in panama. Mobilities 8 (3), 313-330.

Benson, 2009. Migration and the search for a better way of life: a criticalexploration of lifestyle migration. Sociol. Rev. 57 (4), 608-625.

Black R., Natali C., Skinner J, 2005. Migration and inequality, Development Report 2006. Sussex : World Development Research Centre on Migration, Globalisation and Poverty, University of Sussex.

Boyle, P., and Halfacree, K. (Eds.), 1998. Migration into Rural Areas: Theories and Issues. London: Wiley.

[BPS] Badan Pusat Statistik. 2010. Kecamatan Cisarua Dalam Angka 2009. Kabupaten Bogor: Badan Pusat Statistik.

[BPS] Badan Pusat Statistik. 2011. Kecamatan Cisarua Dalam Angka 2010. Kabupaten Bogor: Badan Pusat Statistik.

[BPS] Badan Pusat Statistik. 2012. Kecamatan Cisarua Dalam Angka 2011. Kabupaten Bogor: Badan Pusat Statistik.

[BPS] Badan Pusat Statistik. 2013. Kabupaten Bogor Dalam Angka 2012. Kabupaten Bogor: Badan Pusat Statistik.

[BPS] Badan Pusat Statistik. 2013. Kecamatan Cisarua Dalam Angka 2012. Kabupaten Bogor: Badan Pusat Statistik.

[BPS] Badan Pusat Statistik. 2014. Kabupaten Bogor Dalam Angka 2013. Kabupaten Bogor: Badan Pusat Statistik.

[BPS] Badan Pusat Statistik. 2014. Kecamatan Cisarua Dalam Angka 2013. Kabupaten Bogor: Badan Pusat Statistik.

Casado-Díaz, M., Kaiser, C., Warnes, A., 2004. Northern European retired residentsin nine southern European areas: characteristics, motivations and adjustment. Ageing Soc. 24 (3), 353-38

Castles, S., 2003. Towards a sociology of forced migration and social transformation.Sociology 77 (1), 13-34.

Castles, S.,(1998). "Globalization and Migration: Some Pressing Contradiction", UNESCO. Oxford: Blackwell Publisher.

Croucher, 2009. The Other Side of the Fence: American Migrants in Mexico.University of Texas Press.

O'Reilly, K., 2000. The British on the Costa del Sol: Transnational identities and localcommunities. Routledge, London.

Hayes, M., 2014. 'It is hard being the different one all of the time': Gringos andracialized identity in lifestyle migration to Ecuador. Ethn. Racial Stud. http://dx.doi.or g/10.1080/01419870.2014.943778.

Fawcet, J. T. (1989), "Network, Lingkages, and Migration System International Migration Review" Vol XXIII No. 3.

Goss, J. and Lindquist, B. (1996). "Conseptualising International Labor Migration: Structuration Prespective”. International Migration Review. Vol XXIX. No. 2.

Kritz, M., and Zlotnik, H. (ed.), (1992). "Global Interaction: Migration Systems, Proceses, and Policies" in M. Kritz dan H. Zlotnik (eds) International Migration System: A Global Approach. Oxford: Clarendon Press.

Kolopaking, L.M. 2000. Penghijrahan Tenaga Kerja Antarbangsa dan Pembangunan Daerah Asal di Jawa 
(International labour migration and the development of the sending region in Java). [Disertasi]. Penang: Pusat Pengkajian Kemasyarakatan Universiti Sains Malaysia

Kolopaking, L.M. 2011. Dilemma of International Female Migrant Workers as Agent of Rural Development in Indonesia. APWIN Vol. 12, 2011. Asia Pacific Womens Information Network Center, Sook Myung Women South East University.

Lipton M. 1980. Migration from rural areas of poor countries: the impact on rural productivity and income distribution. World Development 8: 1-24

Massey, D.S. (1989).'International migration and economic development in comparative perspective." Population and Development Review 14: 383-414.

Massey, D.S. (1990). "Social structure, household strategies, and the cumulative causation of migration." Population Index 56: 3-26.

Massey, D.S. et.al., (1993). “Theories of International Migration: A Review and Appraisal, "Population and Development
Review, Vol.19. No.3.

Muhammad Zid, 2010. Belajar dari Panyingkiran dan Ciherang: Antara Resiko dan Manfaat Migrasi Internasional Perempuan Pedesaan. Jurnal Warta Demografi. Tahun Ke 40 No.2. Jakarta: Lembaga Demografi Fakultas Ekonomi Universitas Indonesia

Poeloengan, Lisna Yuliani. 2009. Analisis Kebijakan Pemberdayaan Tenaga Kerja Luar Negeri Dalam Rangka Perbaikan Kualitas Sumber Daya Alam dan Lingkungan Permukiman Daerah Asal. [Disertasi]. Bogor: Sekolah Pascasarjana Institut Pertanian Bogor.

O'Reilly and Benson, 2009. Lifestyle migration: escaping to the good life? In: Benson, M., O'Reilly, K. (Eds.), Lifestyle Migrations: Expectations, Aspirations and Experiences. Ashgate, Surey, England, pp. 1-13.

Wulan, Tyas Retno. 2010. Pengetahuan dan Kekuasaan: Penguatan Remitan Sosial Sebagai Strategi Pemberdayaan Buruh Migran. [Disertasi]. Bogor: Sekolah Pascasarjana Institut Pertanian Bogor. 